\title{
MISTAKES IN SPECIALIST TRANSLATIONS AND THEIR POSSIBLE CONSEQUENCES IN THE LEGAL COMMUNICATION
}

\author{
Eliza Kmiecicka \\ University of Warsaw, Applied Linguistics student, Poland \\ e.kmiecicka@student.uw.edu.pl \\ Mentor: Joanna Osiejewicz \\ University of Warsaw, Poland \\ j.osiejewicz@uw.edu.pl
}

\begin{abstract}
Nowadays, in the age of globalisation and the worldwide flow of information, translator's work becomes more and more demanding as well as indispensable. International legal communication and functioning of multinational institutions and organisations require an effective work of professional legal translators. The legal translation remains a challenge even for the most experienced and knowledgeable translators. The purpose of this paper is to prove the difficulty of legal translator's work that may result in various mistakes in the legal specialist translations. Based on researches on translation mistakes, the paper points out types of potential mistakes in translation, the most common translation mistakes and their possible consequences in the legal communication. It also suggests what should be perceived as essential regarding translator's knowledge and competence and proposes what should be seen as important while trying to avoid some legal translation mistakes.
\end{abstract}

Keywords: legal translation, legal communication, mistakes and difficulties in translation, legal translator's challenges

\section{INTRODUCTION}

The legal translation is a challenge, not only because nearly a perfect knowledge of two language systems is required from a translator, but also because a translator needs to be familiar with two, often highly different from each other, legal systems. The difference between them results in a fact that some specialist terminology that may initially seem to mean the same in both languages, can't be in reality treated as equivalents. As a consequence, it turns out that some terms remain untranslatable and it also means that there occur mistakes in the specialist translation that may not only have serious repercussions for a translator themselves, but also for the course of legal communication, the functioning of various organizations and even for a life of an individual client, being a real person with some vital problems. It's important to know what sort of specific mistakes may occur in the process of 
specialist translation regarding legal communication, their possible consequences and the potential ways of avoiding them.

\section{Materials and Methods}

The main method used to achieve the objectives of this paper was analysing various Polish and foreign authors' works on the theory of translation, characteristics and consequences of globalisation, the functioning of specialist translation in such international organisations as the European Union, the challenges that the legal translators face in the their work, the translation mistakes and difficulties that appear in translating legal texts.

\section{Results and Discussion}

Translation has been defined in a plethora of ways over the years by different scholars. One of the most renowned Polish linguists and translators, Olgierd Wojtasiewicz, included in the book entitled Wstęp do teorii tłumaczenia (An introduction to the theory of translation) his scientific point of view on the concept of translation: „Text $b$ in language $B$ is an equivalent of text $a$ in language $A$ if text $b$ causes the same reaction (a set of associations) as text a does." (Wojtasiewicz 1957: 23) He was also one of the linguists to emphasise the importance of the differences in the cultural traditions in the process of the effective translation, pointing them out as more important and causing more problems for translators than different languages' structures. (Wojtasiewicz 1957: 94-95). Such a point of view on the notion of translation is beyond important for the reflections on the specialist translation in the legal communication. A translator who undertakes translating a text produced in a legal language and therefore containing a variety of legal terminology, needs to create a text that will be understood in a nearly entirely the same way as a source text written in a source language. Without it, it's not possible to perform successful acts of legal communication as if two bodies that use different languages to communicate (e.g. a lawyer and his/her client), want to achieve something together, they need to be given the same set of information to be able to reflect on it with the same chances. The legal terminology relates to various legal systems that are relevant to different countries and hence cultures existing in these countries. Every country and every culture is different in its own way and so are also the legal systems as well as legal terminology systems. That's why the specialist translation is such a challenge and can't be named mechanical, easy and restorative. A legal translator is a person who not only should, but actually must be familiar with two law systems existing in two different cultures of the source language speaking and the translation's language speaking country. It therefore requires enormous competencies. (Ciesielczyk 2009: 108-109).

In the age of globalisation, named sometimes a worldwide revolution (Lemańska-Majdzik, Sobiegraj 2013: 124), there has been formed a whole new space for the work of translators that is indispensable to let two main globalisation's features - the overcoming of spatial obstacles and the central role of access to information, knowledge and science (Bielsa 2005: 131) - exist and develop. The role of translators often tends to be made irrelevant and invisible as it's widely assumed that different sorts of information can circulate all over the world between various countries, cultures and linguistic systems in their original form, remaining unaltered that makes people treat the access to information as something obvious and possible to be achieved effortlessly. (Bielsa 2005: 143) Without the work of the translators and 
interpreters, though, it all won't be possible. The biggest „multicultural, multilingual democracy“ (Apostolou 2011: 99), i.e. the European Union, faces such challenges as the coexistence of a wide array of spoken languages and different cultures on daily basis. The cultural and linguistic diversity are its two core components which need to be taken into consideration and dealt with in its daily functioning that actually poses an enormous challenge for the EU. The equality of the languages of the EU was promoted from its very beginning that results in the fact that this international organisation currently employs 500 permanent interpreters, 2700 accredited interpreters and 300-400 independent interpreters per day, making European Union the biggest employer of the interpreters in the world. The age of globalisation and the more and more new needs of different institutions and organisations not only create an enormous space for the translators' and interpreters' work, but also put a great responsibility on them as even a small mistake in the specialist translation may cause serious problems in communication between different bodies, even on a level of state institutions. (Apostolou 2011: 95-106).

The difficulty of the specialist translation may result in a wide array of various mistakes made by translators, often even well-respected and highly competent ones. They might be of a different character and can be divided into two types: translation mistakes and linguistic mistakes. The linguistic mistakes appear regardless of the languages in which the source and translated text are written, whereas the translation mistakes can be defined as more complicated and regarding more commonly the specialist translations as they often occur in the texts that concern the specific disciplines and fields of studies. The translation mistakes can be then a result of a lack of translator's complete understanding of an original text or of their missing knowledge on the linguistic level or on the level of familiarity with a source text's field. They may also be caused by a lack of knowledge about the rules governing translation, a lack of a proper translation method, a wrong use of translation techniques, a translator's misinterpretation of the source text or an interpretation that differs too much from an original text and also by too close contacts between two languages (false friends, language interferences, anglicisms, etc.). (Pisarska, Tomaszkiewicz, 1996: 144-154).

In the case of legal translations it often comes out that it's extremely difficult or even impossible to find proper equivalents in a translated text's language to terms functioning in a source text's language. The equivalents that may be found in the dictionaries often turn out to be unsatisfactory as they are too generic, too narrow, too precise or that they can't be treated as equivalents to terms in a source text's language at all as their meaning expresses and names something that differs too much from a meaning of a term in the original text. (Gościński 2015: 94) It results in many difficulties in legal translations as well as the legal communication and may lead to translation mistakes.

As Prieto Ramos's work on translation mistakes in the international organisations and his study of corrigenda reveal, there really appear the translation mistakes in legal translations, even in cases of experienced translators' performances for the biggest and most important organisations in the world (such as the European Union, the United Nations, the World Trade Organisation). In all the institutions he investigated, the most frequent were the meaningdistorting content reformulation corrections and the number of them is on increase. The amount of formal mistakes remains stable and the gravity of their semantic impact is usually 
similar to mistakes concerning content reformulation. There appear, though, spelling mistakes, too, such as problems regarding grammar concordance and cohesion problems. (Prieto Ramos 2020: 98) The conclusions of his work show that not only the content reformulation mistakes may have serious repercussions for the legal communication, but also the minor formal mistakes. (Prieto Ramos 2020: 129)

It turns out too that the biggest challenge for a legal translator is not a result of a necessity of using various terms and phrases that are found in specialized dictionaries, but of a need of using all of them properly in a cultural context and in connection with cultural aspects widely common in legal texts. (Chirilă 2014: 492) That's why in the case of legal translations it's extremely important to analyze both an exact meaning of a term in a language of an original text and the meaning of a proposed equivalent in the translated text's language. (Gościński 2015: 94). As a consequence, translators of legal texts need to be prepared for a variety of challenges that not only consist of finding the right equivalent of a term from an original text's language in the translated text's language, but also force them to deal with the untranslatability of certain terms that is a result of the unique character of different legal systems and, therefore, legal terminology used to describe and communicate within their fields. In such cases translators must show their skill at deciding whether a particular term can or cannot be translated directly, and if it cannot be, they need to competently make use of compensatory techniques, such as forming a descriptive translation, using language calques or borrowing source terms from an original text that may require an additional information in a form of a definition in a translator's note. (Chirilă 2014: 488) If a translator doesn't do it properly which means that s/he translates some terms or whole phrases in a wrong way as well as chooses an inappropriate translation technique if a perfect equivalent doesn't exist, it may have serious consequences for the smoothness and comfort of legal communication, both on a lower level of e.g. a lawyer-client communication and on some higher, international ones, in different organisations and institutions and it may result in lawsuits and loss of money, too. (Chirilă 2014: 487).

To avoid a great number of mistakes in specialist translation, it's beyond important to give more focus on the education of translators which is a challenge for the academic community. Without a progress in the improvement of education methods, it won't be possible to perform better translations and develop in this field of study. (Chirilă 2014: 487) It's also of a great importance for a translator to be given a sufficient amount of time for the process of translation and to be aware that the lack of sleep and rest don't have a desired effect on translator's performance. Fatigue, being a result of either a depravation of sleep or long working hours, boredom and monotonous, intense cognitive activities may result in deterioration of person's alertness, reduced decision-making ability, reduced attention, productivity and performance as well as in errors in judgement. (Caldwell et al., 2019: 272-274) A legal translator needs to be both professional in his/her discipline and possess a profound knowledge of two language systems as well as be perfectly familiar with legal systems of the source text's language and the translated text's language and be able to compare them, but also be aware of their own imperfection. (Gościński 2015: 94) Consequently, it's good for a legal translator to be open and willing to consult their uncertainties regarding the original text with their clients as well as possible translation 
techniques and translation decisions with the other legal translators and scholars who specialize in law and in legal science, whose specialistic knowledge on the topic may turn out to be beyond helpful, improve the process of translation and make a positive impact on the quality of a final translation.

\section{CONCLUSIONS}

The field of legal translation is a highly specialized one which results in a fact that there are knowledgeable and professional legal translators needed worldwide. As a consequence of difficulty and complexity of a legal translator's work, there arise many different challenges that a translator needs to face in their everyday work. The case study reveals that there are some specific competencies awaited from a legal translator that can let them perform satisfactory acts of specialist legal translations. It's not only crucial for a legal translator to be perfectly familiar with two different language systems, but also to possess the specialist knowledge of two individual and unique legal systems and legal terminology themselves that function in a source text's language and a translated text's language and, therefore, in different cultures. What is important is the interdisciplinary approach and the knowledge of the cultural context. Without it, it's not possible for a legal translator to understand satisfyingly and fully the context and meaning of an original text and consequently produce a proper translation. A translator needs to be aware of what to do and what kind of translation techniques to use when an adequate equivalent of a term from an original text doesn't exist. It's not favourable to focus only on finding an equivalent as it's not always possible and may turn out to be misleading. A translator must remember the possible compensatory techniques - such as a descriptive translation, language calques, an act of borrowing source terms from an original text - and know how to make use of them properly. All these demands and competencies awaited from a legal translator prove together that a legal translator's work is highly challenging and can't be named mechanical and easy.

As it was reveled in the researches chosen, there really occur mistakes in cases of legal translation, even in performances of most experienced and knowledgeable translators that may work for the most important international organisations, such as the European Union, the United Nations or the World Trade Organisation. Based on the analysed texts on mistakes in the legal translation, the most common and serious mistakes in case of biggest international organisations turn out to be the meaning-distorting content reformulation mistakes and formal mistakes. The biggest amount of mistakes is caused by the difficulty in not only being familiar with two different languages systems, but also the legal systems functioning in different cultures that may result in the lack of proper and exact understanding of an original text and, therefore, in an inaccurate translation. All the mistakes that appear in the legal translation might have serious repercussions for the legal communication and may result in a lack of understanding between different parties taking part in acts of legal communication, parties concerned by the translated legal texts, lawsuits and losses of money.

Since a legal translator's work is so demanding and challenging, it's indispensable to place emphasis on professional, interdisciplinary and efficient education. A legal translator 
should be aware of the value of the interdisciplinary cooperation between them and the specialist in the field of law and law science. Such a specialist may help a legal translator by sparing his/her knowledge on the characteristics of various legal systems that can improve the translator's work and result in better legal translations as well as in more efficient acts of legal communication.

\section{REFERENCES}

Apostolou, F. (2011). Introduction: Interpreting and Translation in the EU. Gramma: Journal of Theory and Criticism, vol. 19, 95-110. https://doi.org/10.26262/gramma.v19i0.6328

Bielsa, E. (2005). Globalisation and Translation: A Theoretical Approach. Language and Intercultural Communication, vol. 5(2), 131-144. https://doi.org/10.1080/14708470508668889

Caldwell, J. A., Caldwell, J. L., Thompson, L. A., Lieberman, H. R. (2019). Fatigue and its management in the workplace. Neuroscience \& Biobehavioral Reviews, vol. 96, 272-289. http://dx.doi.org/10.12775/ RP.2015.004

Chirilă, C. (2014). Errors And Difficulties In Translating Legal Texts. Management Strategies Journal, Constantin Brancoveanu University, vol. 26(4), 487-492.

Ciesielczyk, N. (2009). Analiza problemów tłumaczeniowych przekładu konstytucji Grecji na język polski. Investigationes Linguisticae, vol. 17, 108-128. https://doi.org/10.14746/il.2009.17.8

Prieto Ramos, F. (2020). Facing translation errors at international organizations: What corrigenda reveal about correction processes and their implications for translation quality. Comparative Legilinguistics, vol. 41, 97-133. https://doi.org/10.14746/cl.2020.41.5

Gościński, J. (2015). Tłumaczenie nazw zastępców procesowych w Zjednoczonym Królestwie i Polsce. Rocznik przekładoznawczy, no 10, 75-96. http://dx.doi.org/10.12775/RP.2015.004

Lemańska-Majdzik, A., Sobiegraj, A. (2013). Globalizacja - szansa czy zagrożenie dla współczesnego świata. Zeszyty Naukowe Wyższej Szkoły Humanitas Zarządzanie, no 1, 114-125.

Pisarska, A., Tomaszkiewicz, T. (1996). Wspótczesne tendencje przekładoznawcze, Poznań: Wydawnictwo Naukowe Uniwersytetu im. Adama Mickiewicza w Poznaniu.

Wojtasiewicz, O. (2005). Wstęp do teorii tłumaczenia. Warszawa: Wydawnictwo Tepis Polskiego Towarzystwa Tłumaczy Ekonomicznych, Prawniczych i Sądowych. 